\title{
"Step-by-step" principles of safe laparoscopic approach with technical details in "median arcuate ligament syndrome"
}

\author{
(1) Selçuk Gülmez, M.D.
}

Department of Gastroenterological Surgery, University of Health Sciences, Kartal Koşuyolu High Specialized Training and Research Hospital, İstanbul-Turkey

\begin{abstract}
The median arcuate ligament syndrome (MALS) is a rare cause of postprandial pain and weight loss. The median arcuate ligament (MAL) is a fibrous band of the diaphragmatic crura.Abnormally downward located MAL or high take off of the celiac artery result in external compression the celiac trunk. MAL narrows the truncus coeliacus even more clearly during the expiration. The chronic compression of the celiac artery reduces blood flow and causes symptoms. Symptomatic patients receive surgical treatment, in recent years, an increasing rate, especially laparoscopic. The rate of conversion to open surgery is $10.3 \%$ due to vascular injury in hemorrhage, which generally occurs during dissection. A maneuver is needed to continue with the surgical procedure safely here because of the close neighboring of the aorta, truncus coeliacus, and one of its branches. Technical standardization can reduce the complication rate. There is still no standardized and established laparoscopic method in the world. There are no randomized controlled studies in the literature, which show the superiority of these techniques over one another. The maneuver in this case report, through traction with a tape towards caudal, allows a brilliant view on the celiac axis with shortened operation time. It also makes the operation even safer because of its enabling mastery over the celiac artery and easy dissection.
\end{abstract}

Keywords: Celiac artery compression; intestinal angina; median arcuate ligament syndrome.

\section{INTRODUCTION}

The median arcuate ligament syndrome (MALS), also known as celiac artery compression syndrome, is a rare disease that may cause abdominal pain. MALS was first described by Harjola in 1963, while Dunbar first reported its surgical treatment two years after. ${ }^{[1,2]}$ Minimally invasive procedures have become prominent after 2000 when Roayaie first published a laparoscopic report on MALS, ${ }^{[3]}$ which necessitated symptomatic patients receive surgical treatment. ${ }^{[4]}$ Despite the developments in laparoscopic surgery, the rate of conversion to open surgery is $10.3 \%$ due to vascular injury resulting in hemorrhage, which generally occurs during dissection. ${ }^{[5]}$ Experience and technical standardization can reduce the complication rate. The rare occurrence of the disease as case reports prevented gaining experience and answering the question of which technique is the best. There is still no standardized and established laparoscopic method in the world. There has been an upsurge in the number of publications on the laparoscopic approach recently, and physicians have been trying to standardize the technical details of the procedure in direct proportion to the increase in such reports. ${ }^{[6-8]}$ Median arcuate ligament (MAL) narrows the truncus coeliacus even more clearly during the expiration. ${ }^{[9]}$ Because of that, MAL relaxation is the main goal of surgery. The trend in recent years is to make it laparoscopic. In this case report, we aimed to describe these stages of dissection in steps.

\section{CASE REPORT}

A 39-year-old male presented with postprandial chronic intermittent epigastric pain, occasional nausea and vomiting for

Cite this article as: Gülmez S. "Step-by-step" principles of safe laparoscopic approach with technical details in "median arcuate ligament syndrome”. Ulus Travma Acil Cerrahi Derg 2020;26:642-646.

Address for correspondence: Selçuk Gülmez, M.D.

SBÜ Kartal Koşuyolu Yüksek İhtisas Eğitim ve Araştırma Hastanesi, Gastroenteroloji Cerrahi Kliniği, İstanbul, Turkey

Tel: +90 216 - 500 I 500 /I358 E-mail: selcukgulmez54@hotmail.com 
three years. He had a weight loss of $12 \mathrm{~kg}$ in the last four months. He had not any past medical history and his physical examination, laboratory tests, abdomen sonography, esophagogastroscopy, and colonoscopy were normal. However, the magnetic resonance (MR)-Angiography of the abdomen revealed critical stenosis of the celiac axis (Fig. I). Laparoscopic retrograde MAL-dividing without drain was performed. Subsequently, the patient was free from symptoms and discharged on the $4^{\text {th }}$ postoperative day. He was still symptomfree after 10 months.

\section{The Technical Steps of the Laparoscopic Retrograde Approach}

Step I: Anesthesia, patient positioning, trocar placement: Under general anesthesia, the patient was positioned in supine and the $30^{\circ}$ reverse Trendelenburg position with open legs. The surgeon will perform the surgery between the legs of the patient. A total of 5 ports were used. The location of the initial $10 \mathrm{~mm}$ trocar $\left(30^{\circ}\right.$ camera port) was approximately $5 \mathrm{~cm}$ above the umbilicus. Then, two $5 \mathrm{~mm}$ trocars were placed in the right subcostal region. Laterally of them was as a triangular articulating retractor used. After that, two more $5 \mathrm{~mm}$ trocars were placed in the left subcostal region. The two upper trocars were for working and controlled by the surgeon. The left lateral trocar was used for traction of the structures and vascular tape by the first assistant.

Step 2: Opening of the hepatogastric ligament (Fig. 2a) and identification and isolation of trifurcation of the celiac trunk (Fig. 2b).

Step 3: Passing the vascular tape below the left gastric artery (Fig. 3a) and the A. hepatica communis (Fig. 3b).

Step 4: Traction of the intermediate compartment (Fig. 4a) and joining the intermediate compartment with the first part

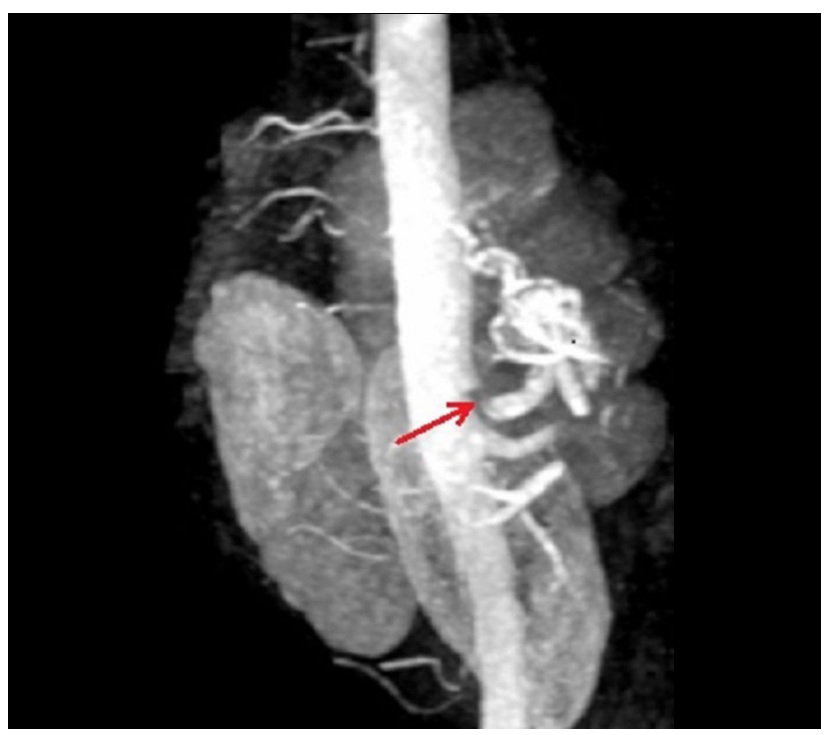

Figure 1. Preoperative MR-angiography, critical stenosis of the celiac axis (arrow).
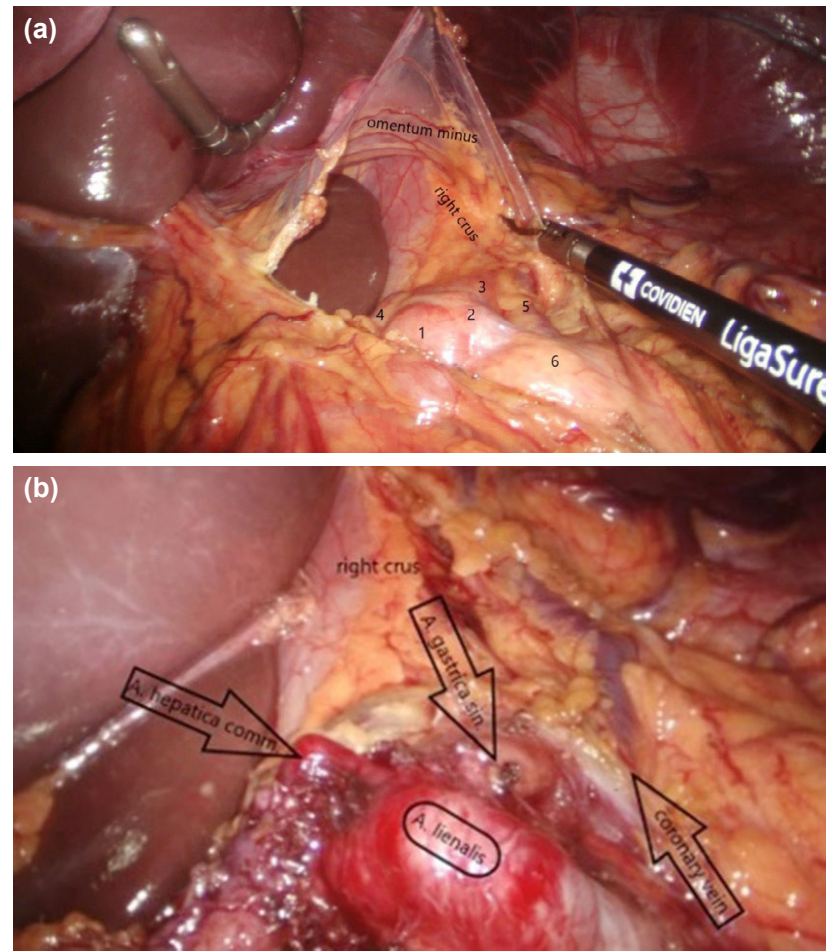

Figure 2. (a) Opening of the hepatogastric ligament (1: lymph node 8a, 2: splenic artery, 3: left gastric artery, 4: a. hepatica comm., 5: coronary vein, 6: pancreas). (b) Identification and isolation of trifurcation of the celiac trunk.
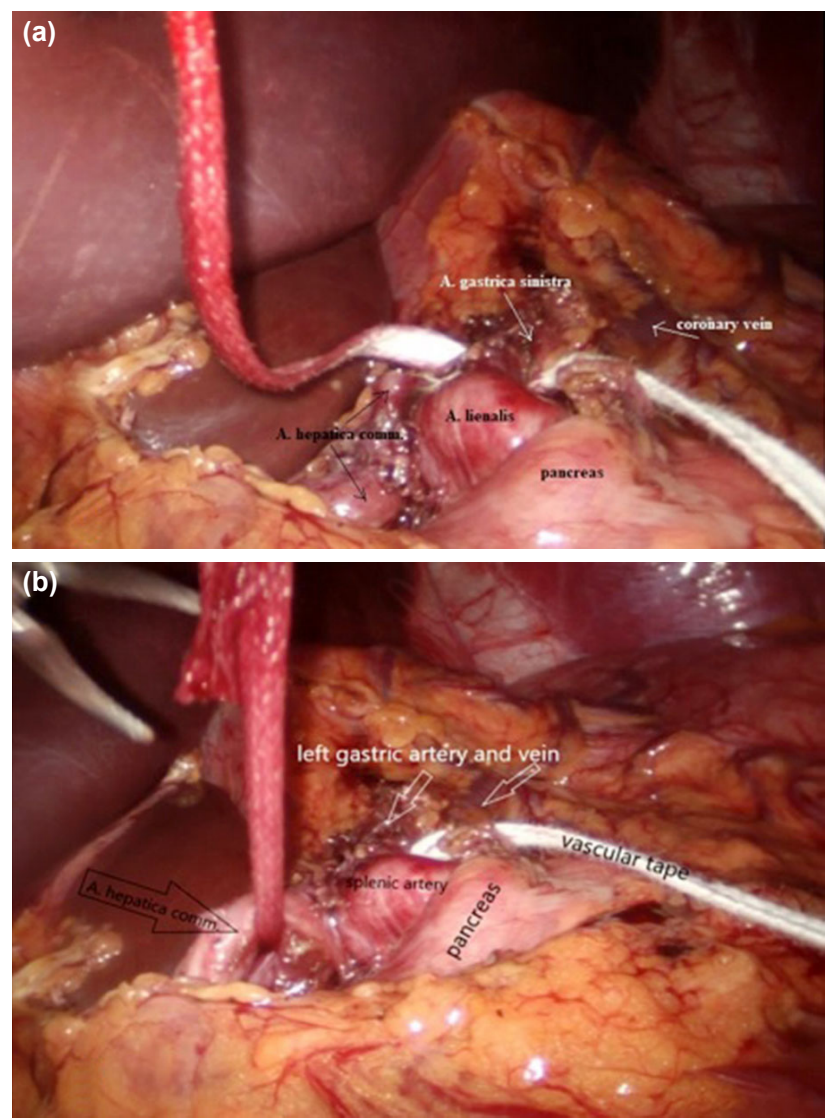

Figure 3. Passing the vascular tape below the left gastric artery (a) and the A. hepatica communis (b). 

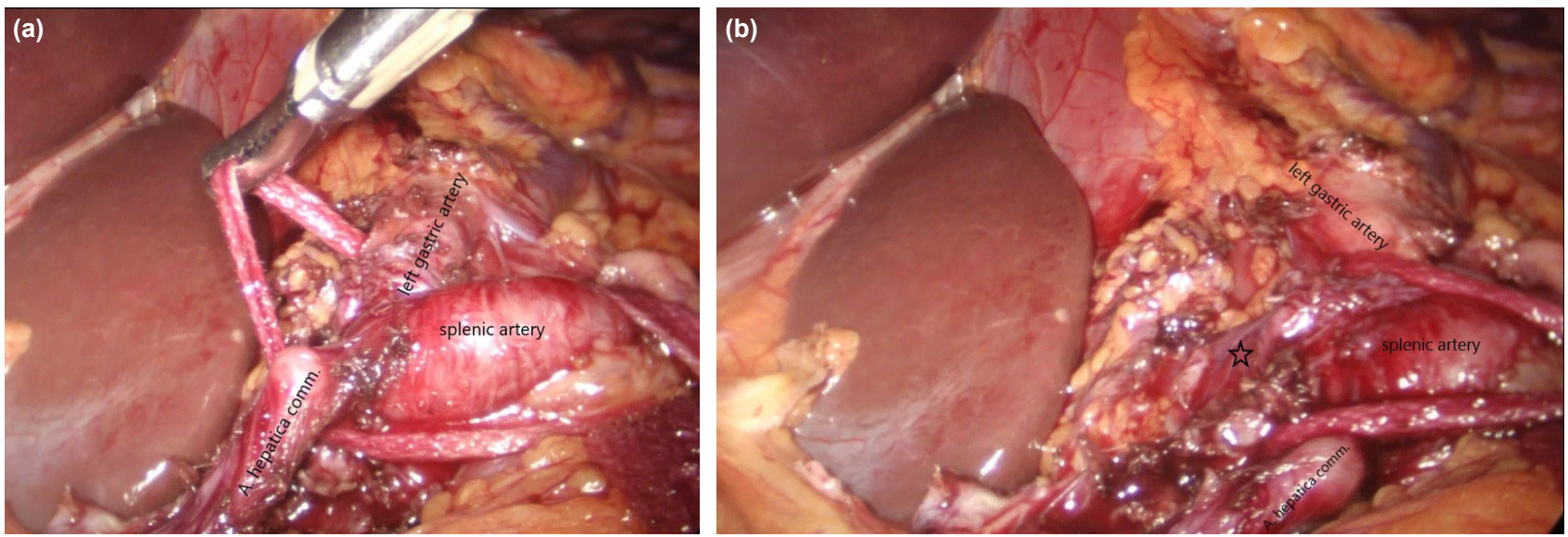

Figure 4. (a) Traction of the intermediate compartment. (b) Joining the intermediate compartment with the first part passing below the arteries. MAL marked with asterisks.
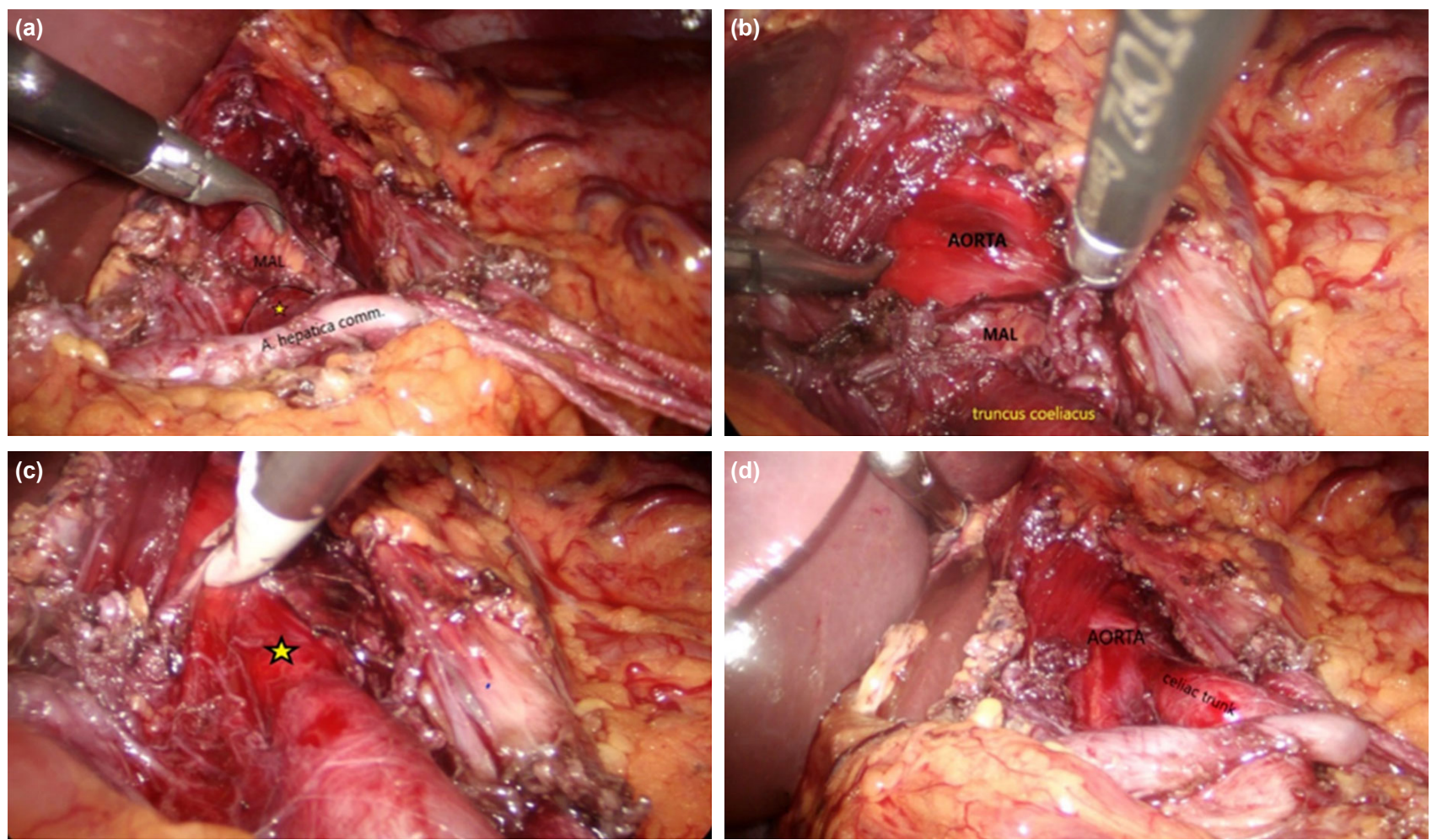

Figure 5. (a) Elevation of MAL. Truncus coeliacus marked with asterisks. (b) Clear isolation and visualization of MAL (ca) Cutting the last part of MAL. Trace of the area where MAL narrows the celiac artery root (marked with asterisks). (d) Final image.

passing below the arteries and traction of both components together towards the caudal (Fig. 4b). Extreme traction and abnormal force exerting should be avoided during this traction process.

Step 5: Dividing of the musculofibrous structures with the celiac plexus ganglion fibers and lymphatics by using ultrasonic energy devices or hook cautery (Fig. 5a-d).

\section{DISCUSSION}

MALS is a rare cause of postprandial pain and weight loss brought about by the external compression of the celiac artery that is generally seen in female patients aged between 30 and $50 .{ }^{10]}$

MAL is a fibrous band of the diaphragmatic crura. Abnormally downward located MAL or high take off of the celiac artery results in external compression celiac trunk. ${ }^{[9]}$ The chronic compression of the celiac artery reduces blood flow and causes symptoms. ${ }^{\left[{ }^{[1]}\right]}$ The pathophysiological mechanism is not yet clear and there is still no consensus. There are two commonly accepted hypotheses about this condition. The first hypothesis is the neurogenic theory, which may arise from direct sympathetic pain or local irritation or indirect splanchnic vasoconstriction brought about by the exter- 
nal compression of the celiac artery. ${ }^{[12]}$ The second theory, known as the steal phenomenon, is the gravitation of the current towards the celiac artery using the collaterals between the mesenteric artery and the celiac artery. ${ }^{[2,13]}$ While De Lara argued that the symptoms could be better explained by the neurogenic theory, ${ }^{[12]}$ Glen et al. ${ }^{[2]}$ stated in their review that the steal phenomenon was more commonly accepted by many specialists.

The symptoms are pronounced, especially during expiration. The murmur in the epigastric area, which becomes especially more prominent during expiration, proves to be a significant clinical finding in the examination of patients. ${ }^{[4]}$

Diagnostic methods include Doppler ultrasonography, CTor MR-Angiography, and selective catheter angiography. ${ }^{\left[{ }^{[1]}\right.}$ Although selective angiography performed for MALS during inspiration and expiration has been set as the gold standard by some publications, ${ }^{[13]}$ MR-Angiography or CT supported by $3 D$ imaging, which are non-invasive methods, are preferred more frequently today. ${ }^{[1]}$

MAL results in asymptomatic compression at a rate between $10 \%$ and $24 \%{ }^{[4]}$ and there is no need for intervention in asymptomatic or incidentally detected celiac artery compression. ${ }^{[14]}$ Endovascular and surgical procedures are listed among the treatment options for symptomatic cases. While stents can be placed by percutaneous transluminal angioplasty endovascularly, this intervention does not usually solve the underlying problem of external compression of the celiac body and frequently necessitates surgical intervention. Therefore, the best results in eliminating the symptoms were achieved by celiac decompression. ${ }^{[13]}$ While it was achieved by this open method initially, it is now performed more prominently by minimally invasive methods (laparoscopic or robotic). ${ }^{[2,8,14]}$

There is still no standard surgical technique as this disease is quite rare, studies on the subject are generally limited to case reports, and there are no large case series. Studies in literature generally offer three different surgical techniques. The first surgical technique is the antegrade approach, which is described by the finding of truncus coeliacus by moving downwards from the upper side of the aorta and continuing with this, ending in the decompression of the MAL on the celiac body. ${ }^{[10]}$ The second surgical technique is the retrograde approach within which the left gastric artery and/or the hepatic artery are found, MAL is cut moving upwards, but the upper side of the artery is not dissected. ${ }^{[7]}$ The final surgical technique is a combined technique that simultaneously utilizes both approaches. ${ }^{[6]}$ There are no randomized controlled studies in the literature, which shows the superiority of these techniques over one another. A maneuver is needed to continue with the surgical procedure safely here because of the close neighboring of the aorta, truncus coeliacus, and one of its branches. We, in our case, enabled MAL decompression using a retrograde approach.
This maneuver, through traction with a tape towards caudal, allows a brilliant view on the celiac axis with shortened operation time. It also makes the operation even safer because of its enabling mastery over the celiac artery and easy dissection.

Informed Consent: Written informed consent was obtained from the patient for the publication of the case report and the accompanying images.

Peer-review: Internally peer-reviewed.

Authorship Contributions: Concept: S.G.; Design: S.G.; Supervision: S.G.; Fundings: S.G.; Materials: S.G.; Data: S.G.; Analysis: S.G.; Literature search: S.G.; Writing: S.G.; Critical revision: S.G.

Conflict of Interest: None declared.

Financial Disclosure: The authors declared that this study has received no financial support.

\section{REFERENCES}

1. A-Cienfuegos J, Rotellar F, Valentí V, Arredondo J, Pedano N, Bueno A, et al. The celiac axis compression syndrome (CACS): critical review in the laparoscopic era. Rev Esp Enferm Dig 2010;102:193-201. [CrossRef]

2. Roseborough GS. Laparoscopic management of celiac artery compression syndrome. J Vasc Surg 2009;50:124-33. [CrossRef]

3. Roayaie S, Jossart G, Gitlitz D, Lamparello P, Hollier L, Gagner M. Laparoscopic release of celiac artery compression syndrome facilitated by laparoscopic ultrasound scanning to confirm restoration of flow. J Vasc Surg 2000;32:814-7. [CrossRef]

4. You JS, Cooper M, Nishida S, Matsuda E, Murariu D. Treatment of median arcuate ligament syndrome via traditional and robotic techniques. Hawaii J Med Public Health 2013;72:279-81.

5. Weber JM, Boules M, Fong K, Abraham B, Bena J, El-Hayek K, et al. Median Arcuate Ligament Syndrome Is Not a Vascular Disease. Ann Vasc Surg 2016;30:22-7. [CrossRef]

6. Berard X, Cau J, Déglise S, Trombert D, Saint-Lebes B, Midy D, et al. Laparoscopic surgery for coeliac artery compression syndrome: current management and technical aspects. Eur J Vasc Endovasc Surg 2012;43:38-42. [CrossRef]

7. Wani S, Wakde V, Patel R, Potankar R, Mathur SK. Laparoscopic release of median arcuate ligament, J Minim Access Surg 2012;8:16-8. [CrossRef]

8. Aday U, Böyük A, Gültürk B, Bozan MB. Safe laparoscopic surgery in median arcuate ligament syndrome. Wideochir Inne Tech Maloinwazyjne 2018;13:539-41. [CrossRef]

9. Duran M, Simon F, Ertas N, Schelzig H, Floros N. Open vascular treatment of median arcuate ligament syndrome. BMC Surg 2017;17:95.

10. Lainez RA, Richardson WS. Median arcuate ligament syndrome: a case report. Ochsner J 2013;13:561-4.

11. Hongsakul K, Rookkapan S, Sungsiri J, Tubtawee T. A severe case of median arcuate ligament syndrome with successful angioplasty and stenting. Case Rep Vasc Med 2012;2012:129870. [CrossRef]

12. de Lara FV, Higgins C, Hernandez-Vila EA. Median arcuate ligament syndrome confirmed with the use of intravascular ultrasound. Tex Heart Inst J 2014;41:57-60. [CrossRef]

13. Kotarać M, Radovanović N, Lekić N, Ražnatović Z, Djordjević V, Lekć D, et al. Surgical treatment of median arcuate ligament syndrome: case report and review of literature. Srp Arh Celok Lek 2015;143:74-8. [CrossRef]

14. Tracci MC. Median arcuate ligament compression of the mesenteric vasculature. Tech Vasc Interv Radiol 2015;18:43-50. [CrossRef] 
OLGU SUNUMU - ÖZET

\section{"Median arcuate ligament sendromu”nda adım adım teknik detaylarıyla beraber güvenli laparoskopik yaklaşımın ilkeleri \\ Dr. Selçuk Gülmez}

Sağlık Bilimleri Üniversitesi Kartal Koşuyolu Yüksek İhtisas Eğitim ve Araştırma Hastanesi, Gastroenteroloji Cerrahi Kliniği, İstanbul

Median arkuat ligament sendromu (MALS), yemek yeme sonrası görülen ağrının ve kilo kaybının nadir bir nedenidir. Median arkuat ligament (MAL), diyafragmatik krusların orta kısmındaki fibröz bir banttır. Anormal olarak aşağı doğru yerleşmiş MAL veya çölyak arterin daha kraniyalden çıkması, çölyak gövdenin dıştan basısı ile sonuçlanır. MAL, trunkus çölyakusu özellikle ekspirium sırasında daha da daraltır. Çölyak arterin kronik olarak sıkışması damar içinden geçen kan akışını azaltır ve semptomlara neden olur. Semptomatik hastalar son yıllarda artan oranda daha çok laparoskopik olarak tedavi edilmektedirler. Laparoskopiden açık cerrahiye dönüşüm oranı az olmayıp \%।0.3'tür, bu da genellikle diseksiyon esnasında ortaya çıkan vasküler yaralanmanın bir sonucu olan kanama nedeniyledir. Aort, trunkus çölyakus ve dallarının birbirleriyle olan yakın komşuluğu nedeniyle mevcut cerrahi prosedürün güvenli bir şekilde devam ettirilmesi için bir manevra gereklidir. Bu manevra ile cerrahi tekniğin standardize edilmesi komplikasyon oranlarını azaltabilir. Bu konuda hala dünyada standartlaşmış ve yerleşik herhangi bir laparoskopik yöntem yoktur. Literatürde var olan tekniklerin birbirlerine üstünlüğünü gösteren herhangi bir randomize kontrollü çalışma yoktur. Bu olgu sunumunda, teknik detayları verilen manevra ile ameliyatın süresi kısalmakta, ayrıca çölyak gövdede mükemmel bir görüntü sağlanmaktadır. Yanısıra, çölyak arter üzerindeki hakimiyeti de kolaylaştırtığından ameliyatı daha da güvenli kılar.

Anahtar sözcükler: Çölyak arter kompresyonu; intestinal angina; median arkuat ligament sendromu.

Ulus Travma Acil Cerrahi Derg 2020;26(4):642-646 doi: 10.14744/tjtes.2019.61559 